\title{
Rancang Bangun Alat Ukur Uji Emisi Gas Karbon Monoksida (CO) Berbasis Mikrokontroler
}

\author{
Semuel Kete Sarungallo ${ }^{1}$, I Gusti Putu Raka Agung ${ }^{2}$, Lie Jasa ${ }^{3}$
}

\begin{abstract}
Carbon monoxide is gas that harmful to health . Carbon monoxide is caused by motor vehicles that are not well maintened, so we need device can measure the levels of carbon monoxide. Measuring instrument created using sensor MQ - 7 based arduino uno R3 . Sensor MQ - 7 is a sensor sensitive to carbon monoxide, stable power supply 5 volts and can measure from 20-2000 ppm of carbon monoxide. Output device is data on the LCD and ISD1820 voice module, so it can be installed in an office basement .
\end{abstract}

Intisari- Gas karbon monoksida merupakan gas yang berbahaya bagi kesehatan. Gas karbon monoksida umumnya desebabkan oleh kendaraan bermotor. Perawatan kendaraan yang tidak berkala menyebabkan peningkatan gas karbon monoksida sehingga dibutuhkan alat yang dapat mengukur kadar gas karbon monoksida. Alat ukur uji emisi gas karbon monoksida yang dibuat dalam penelitian ini merupakan sebuah alat untuk mengetahui kadar gas karbon monoksida menggunakan sensor MQ-7 berbasis arduino uno R3. Sensor MQ-7 merupakan sensor yang sensitif terhadap karbon monoxida, stabil menggunakan catu daya 5 volt dan dapat mengukur dari 20 - 2000 ppm gas karbon monoksida. Keluaran alat berupa data pada LCD dan modul suara ISD1820, sehingga bisa di pasang pada basement perkantoran.

Kata Kunci- Gas CO, Arduino Uno R3, Sensor MQ-7, ISD1820.

\section{PENDAHULUAN}

Meningkatnya pencemaran udara berbanding lurus dengan meningkatnya pengguna kendaraan bermotor. Penguna kendaraan bermotor yang tidak melakukan perawatan berkala akan meningkatkat emisi gas buang. Peningkatan emisi gas buang tersebut dapat dicegah dengan kesadaran para pengguna kendaraan bermotor untuk melakukan perawatan secara berkala.

Gas karbon monoksida (CO) merupakan penyumbang terbesar dalam pencemaran udara sekitar 59\% dari emisi gas buang menggunakan bahan bakar bensin[1]. Polusi karbon monoksida dapat menyebabkan berbagai penyakit seperti ganguan paru - paru, konsentrasi unsur darah yang berkurang dan bahkan serangan jantung[1]. Pengukuran kadar karbon monoksida membutuhkan waktu dan biaya yang tidak sedikit. Hal ini menjadi kendala bagi pengendara kendaraan.

\footnotetext{
${ }^{1}$ Mahasiswa, Jurusan Teknik Elektro dan Komputer Fakultas Teknik Unuversitas Udayana, dusun Bonoran -Kec. Kesu' - Toraja utara-Sulawesi selatan 91852 INDONESIA(tlp: 085255585655; email: semuel_loejho23@yahoo.com)

${ }^{2}$ Dosen Jurusan Teknik Elektro dan Komputer Fakultas Teknik Universitas Udayana, Br. Anggarkasih, Medahan, Blahbatuh, Gianyar, Bali 80581 INDONESIA (telp: 081999898301; e-mail: igapraka@yahoo.co.id)

${ }^{3}$ Dosen Jurusan Teknik Elektro dan Komputer Fakultas Teknik Universitas Udayana, Jl Gunung Merapi No 22, Denpasar, Bali 80119 INDONESIA(telp: 08123931535; e-mail:liejasa@unud.ac.id)
} Semuel Kete Sarungallo : Rancang Bangun Alat Ukur (...)
Pada penelitian sebelumnya telah dibuat alat ukur konsentrasi karbon monoksida menggunakan sensor TGS 2201 dan hasilnya ditampilkan pada LCD[2]. Sensor TGS 2201 merupakan sensor yang dapat mengukur karbon monoksida dan karbon dioksida sehingga sensor tidak berfokus pada pengukuran satu zat saja.

Penelitian ini mengkhususkan pengukuran terhadap karbon monoksida menggunakan sensor MQ-7 dan keluaran alat berupa data pada LCD dan modul suara ISD1820. Keluaran suara ISD 1820 yang ditambahkan diharapkan dapat memberitahu pengguna saat $\mathrm{CO}$ melebihi ambang batas tanpa melihat pada LCD.

\section{UJI EMISI GAS KARBON MONOKSIDA}

\section{A. Pencemaran Lingkungan Akibat Emisi gas Co}

Pencemaran lingkungan menjadi sebuah fenomena saat ini termasuk pencemaran udara. Pencemaran udara ialah penurunan kualitas udara dimana tercampurnya udara dengan bahan kimia atau bahan lainnya yang dapat membahayakan makhluk hidup termasuk di dalamnya manusia. Pencemaran udara saat ini disebabkan oleh banyaknya hasil emisi gas buang dari kendaraan bermotor. Hasil emisi gas buang tersebut menyumbang paling banyak karbon monoksida sekitar 59 persen. Dampak dari polusi yang dihasilkan karbon monoksida terhadap tubuh manusia ialah mengganggu hemoglobin yang berfungsi mengantar oksigen ke seluruh tubuh. Terganggunya hemoglobin yang berfungsi untuk mengikat oksigen berarti berkurangnya oksigen yang sangat diperlukan oleh tubuh manusia. Berkurangnya oksigen dalam tubuh menyebabkan sesak nafas, mual, sakit kepala, kelelahan sampai tidak sadarkan diri dan dapat menyebabkan kematian[3].

Pencemaran gas karbon monoksida bukan hanya berdampak pada manusia saja. Dampak pencemaran karbon monoksida juga berbahaya bagi kelangsungan hidup flora dan fauna. Dampak polusi bagi tumbuhan seperti terjadinya penurunan tingkatan kandungan enzyme, gangguan respon fisiologis dan pada fotosintesa[4]. Dampak pencemaran bagi fauna tidak terlalu jauh bedanya seperti pada manusia.

B. Sensor MQ-7

Sensor MQ-7 merupakan sensor gas yang sensitive dengan gas karbon monoksida. Sensor ini dapat mengukur dari 202000 kadar gas karbon monoksida dalam bentuk ppm. Bahan detektor gas adalah metal oxida $\mathrm{SnO}_{2}$, dimana ketika bahan metal oxida dihangatkan pada temperatur tertentu, oksigen akan diserap pada permukaan kristal dan bermuatan negatif. Hal ini disebabkan karena permukaan kristal mendonorkan elektron pada oksigen yang terdapat pada lapisan luar sehingga oksigen bermuatan negatif. Permukaan luar Kristal akan bermuatan positif sehingga membuat tegangan permukan menghambat aliran laju electron.

p-ISSN:1693 - 2951; e-ISSN: 2503-2372

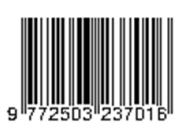




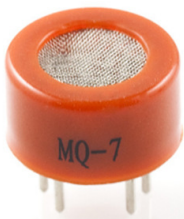

Gambar 1: Sensor MQ-7

Sensor MQ-7 memiliki enam pin empat diantaranya digunakan untuk menjemput sinyal, dan dua diantaranya sebagai penyedia dari heating current. Pada perancangan alat ukur uji karbon monoksida (CO), tiga pin terhubung pada sumber tegangan, satu pin terhubung pada arduino sebagai pemberi sinyal, dan dua pin terhubung pada resistor $10 \mathrm{k} \Omega$ dan ground.

\section{Arduino Uno R3}

Arduino Uno R3 merupakan perangkat elektronika yang mempunyai komponen utama berupa chip mikrokontroler. Mikrokontroler atau IC (integrated circuit) yang digunakan bertipe ATmega 328. ATmega ini merupakan seri CMOS dan berbasis arsitektur RISC[5]. Secara umum, arduino terdiri dari hardware dan software arduino, hardware berupa papan input/output, yang open source dan software Arduino yang juga open source, meliputi software Arduino IDE untuk menulis program dan driver sebagai koneksi dengan komputer. Pada penelitian ini arduino digunakan sebagai komponen untuk memproses data. Data masukan dari sensor MQ-7 melalui pin analog akan diproses pada arduino dan keluarannya berupa data pada LCD dan ISD 1820.

\section{Tampilan dan Keluaran}

Tampilan dan keluaran berupa berupa tulisan dalam bentuk LCD dan suara menggunakan Modul ISD1820. Keluaran pada alat menggunakn pin digital output dari Arduini Uno.

1. LCD atau Liquid Cristal Display adalah suatu jenis media tampil yang menggunakan kristal cair sebagai penampil utama. LCD menggunakan 2 bahan yang dapat mempolarisasikan kristal cair diantara 2 lembaran tersebut[6]. Pada perancangan alat ukur uji karbon monoksida menggunakan LCD 2x16. Rangkaian LCD ini akan berfungsi ketika mendapat tegangan Vec +5Volt.

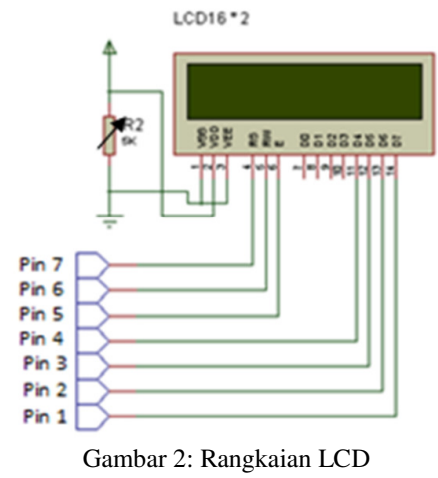

A. Perancangan hardware

Perancangan rangkaian hardware pada pembuatan alat ukur uji emisi gas karbon monoksida dengan sensor MQ-7 berbasis arduino uno R3 menggunakan program Proteus sp7.3 


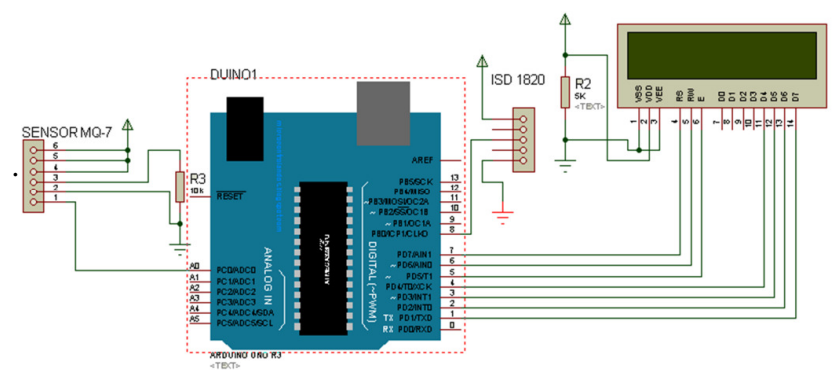

Gambar 4: Perancangan rangkaian keseluruhan

Cara kerja peralatan ini adalah seperti berikut. Ketika sensor MQ-7 mendeteksi adanya gas CO, maka sensor mengirim data ke arduino uno R3. Data tersebut diolah dan ditampilkan pada LCD sebagai output. Jika pembacaan sensor melebihi ambang batas maka Arduino uno R3 mengirimkan sinyal pada module ISD 1820.

B. Perancangan software

Perancangan perangkat lunak (Software) dalam mengimplementasikan alat ukur uji gas karbon monoksida berbasis arduino uno R3 dengan bahasa pemrograman $\mathrm{C}$. Software ini hampir sama dengan IDE (Intergrated Development Environment).

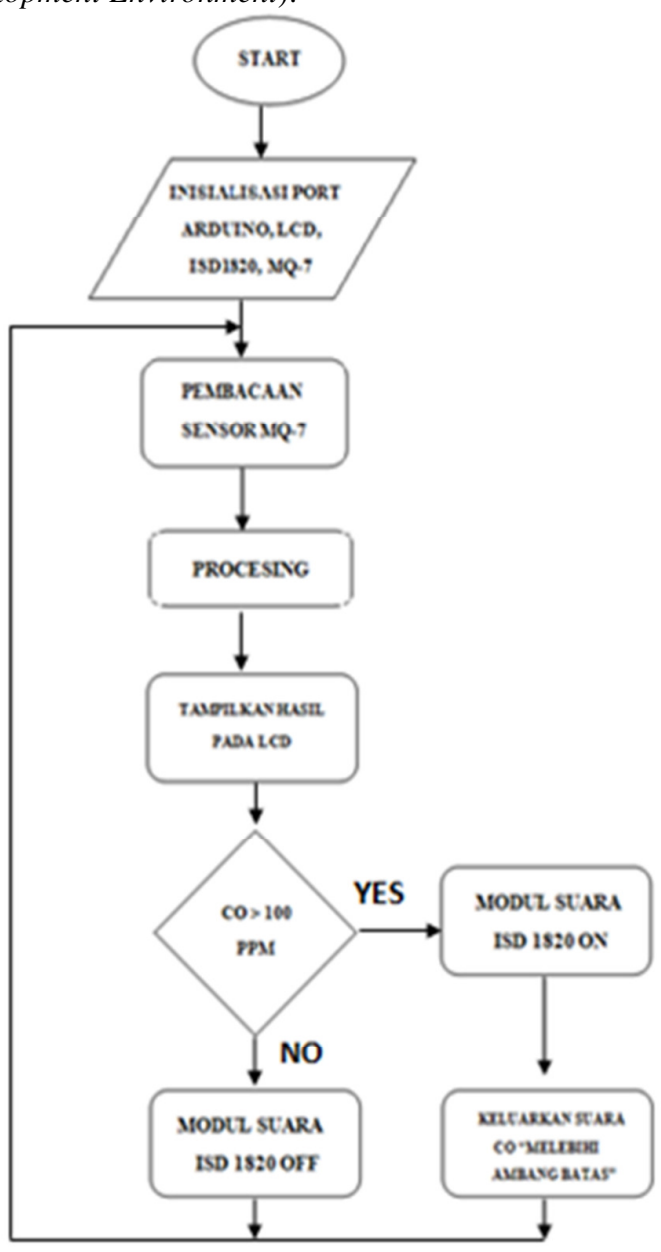

Gambar 5: Flowchart Perancangan software
Diagram alir (flowchart) program dari alat ditunjukkan pada gambar 5 . Pertama adalah inisialisasi Arduino uno R3, LCD, sensor gas MQ-7, modul ISD 1820 dan siap untuk beroperasi, ketika mendeteksi gas karbon monoksida, akan diolah pada arduino uno R3 dan ditampilkan pada LCD. Modul ISD 1820 akan berbunyi " karbon monoksida melebihi ambang batas" jika gas karbon monoksida melebihi 100 ppm. C. Pengujian alat

Pengujian alat yang dibuat dilakukan dengan cara menguji setiap komponen elektronika yang digunakan. Pertama menguji pin - pin pada arduino . Pin arduino yang diuji yaitu power pin, pin digital input dan output, pin analog. Power pin diuji dengan cara mengukur tegangan menggunakan voltmeter. Pin digital input dan output diuji dengan cara memberikan logika high dan low pada pin dan keluarannya dilihat pada lampu LED. Pin analog diuji dengan cara pembacaan sinyal menggunakan potensio meter. Hasilnya diukur dengan multimeter dan ditampilkan pada serial monitor software arduino. Pengujian sensor mq-7 dilakukan dengan cara memberikan paparan gas Co pada sensor dan hasilnya dilihat pada LCD dalam bentuk satuan ADC.

D. Pengambilan data

Pengambilan data dilakukan menggunakan empat merk kendaran bermotor. Kendaraan bermotor yang digunakan yaitu motor 2 tak dan 4 tak masing - masing 2 kendaraan. Motor 2 tak yang digunakan adalah vespa piagio tahun 1996 dan tahun 1976. Motor 4 tak yang digunakan adalah Honda Vario 2016 dan Honda Beat 2014.

E. Analisa data

Setelah melakukan pengujian dan pengambilan data maka langkah selanjutnya yaitu analisa data. Analisa data dari hasil penguran dibandingkan dengan alat yang ada. Alat pengukuran standar yang digunakan yaitu dekko Fm 7010.

\section{HASIL DAN PEMBAHASAN}

A. Realisasi Perancangan Alat

Realisasi rancang bangun alat ukur uji emisi gas karbon monoksida dapat dilihat pada gambar 6 .

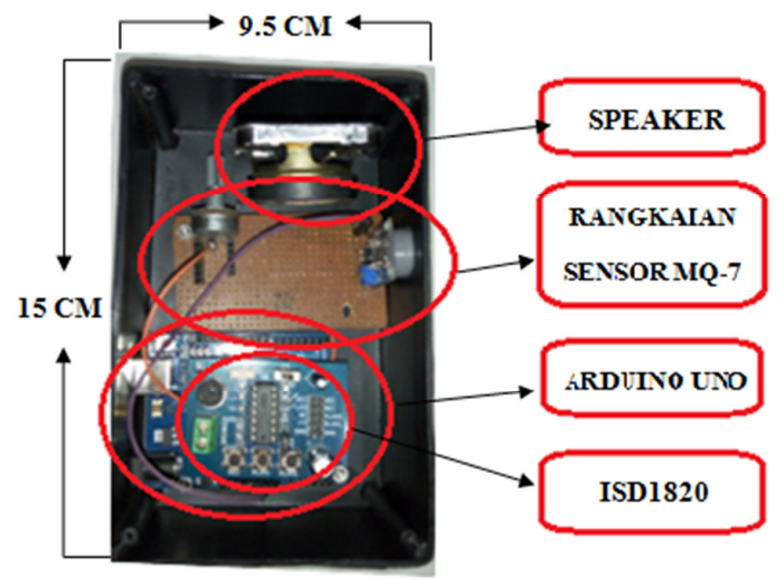

Gambar 6: Realisasi alat ukur uji emisi gas karbon monoksida 


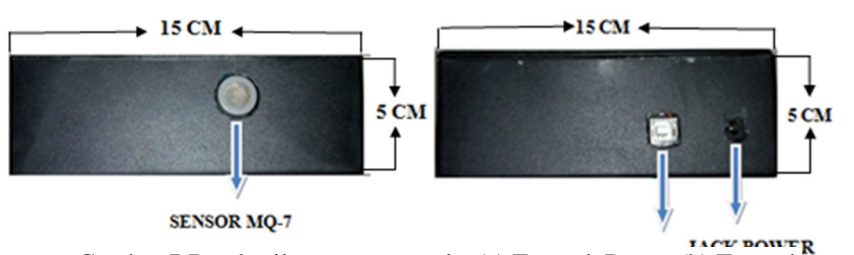

Gambar 7:Box hasil perancangan alat (a) Tampak Depan (b) Tampak Belakang

Tabel 1: Dimensi Box Alat ukur uji emisi gas karbon monoksida

\begin{tabular}{|c|c|c|}
\hline No & Spesifikasi & Rangkaian \\
\hline 1 & Tinggi & $5 \mathrm{~cm}$ \\
\hline 2 & Panjang (permukaan) & $15 \mathrm{~cm}$ \\
\hline 3 & Lebar (Permukaan) & $9,5 \mathrm{~cm}$ \\
\hline 4 & Power Supply & Adaptor $12 \mathrm{~V} \mathrm{1,5A}$ \\
\hline 5 & Mikrokontroler & ATmega 328 \\
\hline 6 & Tampilan & LCD $16 \times 2$ \\
\hline
\end{tabular}

B. Kalibrasi sensor MQ-7

Kalibrasi yang dilakukan merujuk pada data penelitian sebelumnya tentang hubungan ppm, ADC, RS dan RS/RO. Hasil data dapat dilihat pada tabel 2 .[7].

Tabel 2: Hubungan antara ADC, ppm, RS dan RS/RO

\begin{tabular}{|l|l|l|l|}
\hline ADC & PPM & Rs & Rs/Ro \\
\hline 337 & 20 & 20,3 & 2,95 \\
\hline 416 & 40 & 14,5 & 2,11 \\
\hline 494 & 60 & 10,6 & 1,15 \\
\hline 564 & 80 & 8,1 & 1,18 \\
\hline 606 & 100 & 6,9 & 1 \\
\hline 639 & 120 & 6,0 & 0,88 \\
\hline 676 & 140 & 5,1 & 0,75 \\
\hline 699 & 160 & 4,6 & 0,67 \\
\hline 730 & 180 & 4,0 & 0,58 \\
\hline 760 & 200 & 3,4 & 0,5 \\
\hline
\end{tabular}

Data dari tabel 2 terlihat bahwa ketika gas Co ditambahkan maka hasil pembacaan sensor juga ikut bertambah. Penambahan gas $\mathrm{CO}$ dalam bentuk ppm diikuti bertambahnya pembacaan ADC oleh arduino. Untuk menggunakan ploting data maka digunakan persaman regresi menggunakan program excel. Karena yang digunakan dalam penelitian hanya hubungan antara ADC dan ppm maka dibuatkan kurva regresinya seperti terlihat pada gambar 7 .
PPM

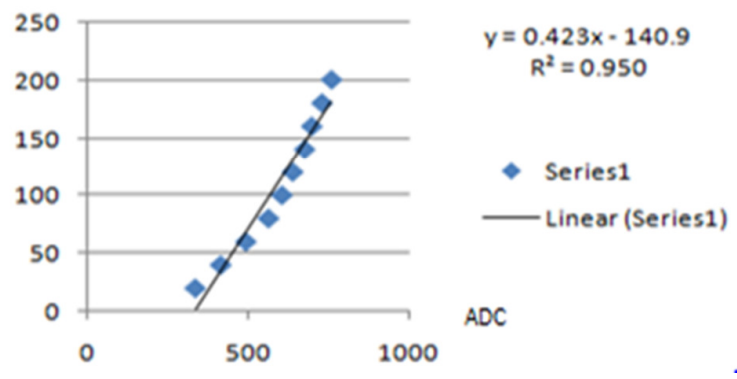

Gambar 7: grafik hubungan antara ADC dan ppm

Pada gambar 7 didapatkan persaman regresi $\mathrm{Y}=0,423 \mathrm{x}-$ 140,9. Tetapi dari gambar 7 , dapat dilihat garisnya tidak terlalu linear dan lebih mirip kurva logaritmik. Penulis memutuskan menggunakan fungsi logaritma pada PPM dan pembagian 100 pada ADC sehingga gapnya tidak terlalu jauh. Hasilnya dapat dilihat pada tabel 3 .

Tabel 3: Hubungan antara ADC/100 dan log ppm,

\begin{tabular}{|l|c|}
\hline ADC/100 & LOG PPM \\
\hline 3,37 & 1.301 \\
\hline 4,16 & 1.602 \\
\hline 4,94 & 1.778 \\
\hline 5,64 & 1.903 \\
\hline 6,06 & 2.000 \\
\hline 6,39 & 2.079 \\
\hline 6,76 & 2.146 \\
\hline 6,99 & 2.204 \\
\hline 7,30 & 2.255 \\
\hline 7,60 & 2.301 \\
\hline
\end{tabular}

Dari data tabel diatas maka dibuatkan lagi persaman regresinya dan hasilnya dapat dilihat pada gambar 8 .

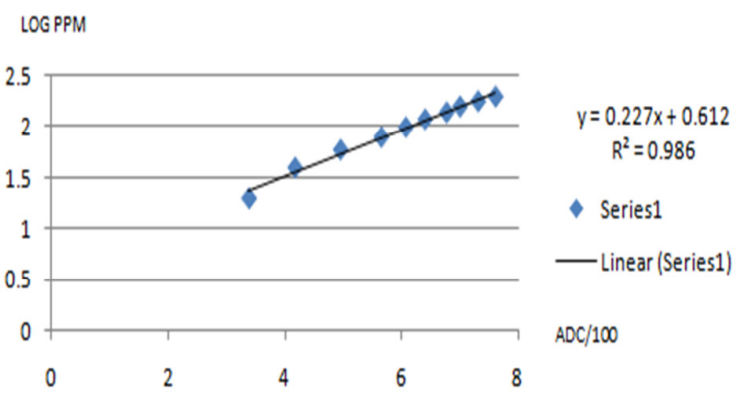

Gambar 8: Hubungan antara ADC/100 dan LOG PPM 
Data antara hubungan Log ppm dan ADC/100 sudah terlihat linear sehingga rumus ploting data regresi linear telah memenuhi syarat dan persamaan yang didapatkan yaitu :

$$
Y=0,227 X+0,612
$$

Dimana : $\mathrm{Y}=\mathrm{LOG}$ PPM,

$$
\mathrm{X}=\mathrm{ADC} / 100
$$

sehingga persamaannya menjadi :

$\log \mathrm{PPM}=0,227(\mathrm{ADC} / 100)+0,612$

$$
\begin{aligned}
& \mathrm{PPM}=10^{0,227(\mathrm{ADC} / 100)} * 10^{0,612} \\
& \mathrm{PPM}=4,0926\left(10^{0,227(\mathrm{ADC} / 100)}\right)
\end{aligned}
$$

Rumus yang didapatkan kemudian digunakan untuk mengubah data dalam bentuk ADC ke bentuk ppm. Untuk mengetahui perbandingan hasil perhitungan dengan alat sebenarnya maka dilakukan pengujian dengan alat $\mathrm{CO}$ meter merk Dekko FM-7910. Pengujian dilakukan pada motor Honda Vario keluaran 2012. Cara pengujiannya dengan meletakkan alat yang dibuat berdampingan dengan alat $\mathrm{CO}$ meter sehingga hasilnya langsung dapat dilihat pada tampilan LCD, seperti pada gambar 9 .

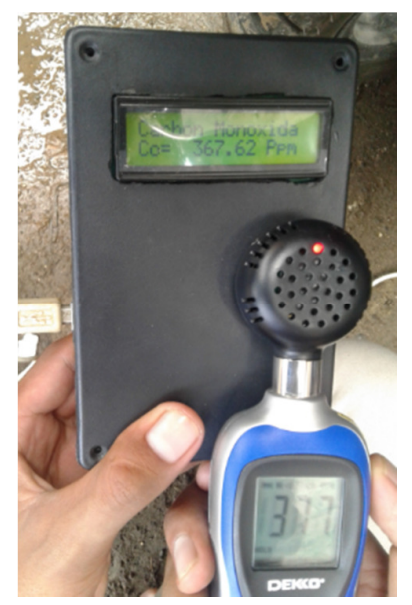

Gambar 9: Hasil pengukuran dengan alat sebenarnya

Gambar 9 menunjukkan perbandingan alat uji emisi karbon monoksida yang dibuat dengan alat $\mathrm{CO}$ meter merk Dekko FM-7910. Hasil pada alat yang dibuat menunjukkan gas yang diukur masih ada selisih sekitar 10 PPM, jika dibawa ke dalam bentuk persen maka kesalahan sebesar :

$$
\left(\frac{377-367}{377}\right) \times 100 \%=2,7 \%
$$

Dari data kalibrasi hasil yang didapatkan menunkukkan perbedaan range $2,7 \%$. Untuk alat pengukuran $\mathrm{CO}$ standar margin eror yang bisa di terima sampai $5 \%$. Ini menunjukkan alat yang dibuat margin erornya bisa diterima.

C. Pengujian pada motor

Sebelum dilakukan pengujian pada kendaraan bermotor, kendaran dinyalakan sekitar 2-3 menit untuk menstabilkan gas buang. Setelah itu dilakukan pengukuran dengan cara meletakkan alat uji emisi gas karbon sekitar 5-7 cm dari knalpot kendaraan. Alat ini ditera dengan alat ukur standard dekko FM 7010. Caranya meletakkan alat ukur uji yang dibuat dengan dekko fm 7010 secara bersamaan pada bibir knalpot sehingga data yang ditampilkan terlihat pada LCD.
Pengukuran sampel kendaraan bermotor dilakukan pada 4 merk motor, 2 jenis dua tak dan 2 jenis 4 tak. Untuk hasilnya bisa dilihat pada table 4.

\begin{tabular}{|c|c|c|c|}
\hline To Tabel 4: Data Hasil Pengukuran \\
\hline 1 & $\begin{array}{c}\text { Jenis Motor } \\
\text { Honda Beat } \\
2013\end{array}$ & $\begin{array}{c}\text { Pengukuran } \\
\text { dengan Dekko } \\
\text { Fm }\end{array}$ & $\begin{array}{c}\text { Pengukuran } \\
\text { denganAlat } \\
\text { yang dibuat }\end{array}$ \\
\hline 2 & $\begin{array}{c}\text { Honda Vario } \\
2016\end{array}$ & $296 \mathrm{Ppm}$ & 360 Ppm \\
\hline 3 & $\begin{array}{c}\text { Vespa Piagio } \\
1996\end{array}$ & $790 \mathrm{Ppm}$ & $782 \mathrm{Ppm}$ \\
\hline 4 & $\begin{array}{c}\text { Vespa Piagio } \\
1976\end{array}$ & Over Load & Over Load \\
\hline
\end{tabular}

Hasil yang didapatkan dari tabel 4 menunjukkan adanya perbedaan antara alat ukur yang dibuat dengan alat ukur standar dekko FM 7010. Perbedaannya berkisar antara 0,7 \% sampai $2,7 \%$. Hal seperti ini mungkin disebabkan beberapa faktor eror seperti gas polutan yang berubah -ubah dan tata letak antara dekko fm 7010 dan knalpot dan alat ukur yang dibuat tidak berapa pada posisi yang persis sama. Data dari vespa piagio tahun 1976 tidak bisa diukur menggunakan Dekko FM 7010 dan alat ukur uji emisi yang dibuat karena pengukuran karbon monoksidanya yang melebihi kapasitas.

\section{KESIMPULAN}

Adapun simpulan yang dapat diambil dari hasil pengujian dan pembahasan yang telah dilakukan mengenai alat ukur uji emisi gas karbon monoksida adalah sebagai berikut:

1. Alat ukur uji emisi gas karbon monoksida (CO) yang dibuat dapat bekerja dengan baik, melalui sensor MQ-7 berbasis Arduino uno R3 dengan batas pengukuran dari 5 - 860 Ppm.

2. Alat ukur uji emisi gas karbon monoksida ( $\mathrm{CO}$ ) yang dibuat dibandingkan dengan CO meter Dekko FM 7910 yang dapat mengukur Co dari 1-1000 Ppm menunjukkan hasil dengan kesalahan 2,7 \% yang diukur pada kendaraan Honda Vario 2012.

\section{REFERENSI}

[1] Wisnu, A.W. 1995. Dampak Pencemaran Lingkungan, Andi offset, Yogyakarta.

[2] Victor V. Kosegeran, 2013. Perancangan Alat ukur Kadar karbon monoksida pada gas buang kendaraan bermotor vol 2 no 3: Universitas Sam Ratulangi.

[3] Sugiarti, 2010 gas pencemaran udara dan pengaruh bagi kesehatan Manusia. UNM Makassar.

[4] Arif budiyono,2010. Dampak Pencemaran udara bagi lingkungan,

[5] Swamardika IBA, 2015. Rancang Bangun Robot 6WD Sebagai Alat Pendeteksi Kebocoran Gas Berbasis Komunikasi Wireless XBee-Pro series $160 \mathrm{~mW}$ : Teknik Elektro Universitas Udayana.

[6] Nova Paramarta, 2016. Rancang Bangun Pendeteksi Kebocoran LPG Menggunakan Sensor TGS 2610 Dilengkapi SMS Berbasis Mikrokontroler ATmega 328; Teknik Elektro Universitas udayana.

[7] Fathur, 2015. Instrument Kalibrasi sensor MQ-7. Yogyakarta 